\title{
The London School of Tropical Medicine.
}

THE London School of Tropical Medicine, which in its new domicile in the Hospital for Tropical Diseases in Endsleigh Gardens, Euston Road, London, recently, under Royal auspices, commemorated its nativity, came into being twenty-one years ago.

The idea of a school emanated from Sir Patrick

improved, additional whole-time teachers were appointed, a helminthologist and a protozoologist in 1905 and a medical entomologist in 1907 , and so gradually the laboratory teaching became both fuller and more intensive.

Thus prior to the war the school in its sequestered situation at the docks had assumed its present stature, if not its present finish. It had been affiliated to London University; the practical worth of its curriculum was held in world-wide regard by the medical profession; its bead-roll included the names of nearly two thousand students drawn from every medical vocation and medical service in the tropical Dominions, as well as from many foreign countries; it had undertaken fifteen oversea expeditions for the study of specific pathological problems; and it was steadily countenanced by annual grants from official sources. That at this stage the school had also acquired public esteem outside official and professional circles may be inferred from the benefactions for the advancement of knowledge that were entrusted to its administra-

Fig. r. - The museum, London School of Tropical Medicine.

Manson, who at the time was Medical Adviser to the Colonial Office; it was at once grasped by his farseeing official chief, the late Right Hon. Joseph Chamberlain; and it was aptly embodied forthwith in the benign fabric of the Seamen's Hospital Society, the solicitude of which for the brotherhood of the sea includes all the tropics in its range.

Not only did the society accept the idea, it also magnanimously advanced the funds needed for its realisation, and in October, r899, the young school was actually established, under the ægis of Sir Patrick Manson, as an adjunct to the society's branch hospital at the Albert Dock.

The school was, above all, designed to give practical training in the fundamental laboratory methods of investigating disease while keeping the laboratory in touch with the wards of the hospital, and collating the lessons of laboratory and clinic in set lectures by specialists versed in the medical and sanitary problems of the tropics, the ultimate object being not merely to teach a class how the prevalent diseases of tropical countries are recognised and treated, but also to train the individual man for the experimental investigation of disease in the course of his own career and field of opportunity abroad. It was, moreover, recognised as a vital necessity that members of the teaching staff should go afield from time to time in order to keep in touch with tropical diseases in their endemic areas.

In the early days of the school the main laboratory course was, perforce, conducted by a single wholetime teacher; but as-thanks to the powerful advocacy of $\mathrm{Mr}$. Joseph Chamberlain-the financial position No. 2675 , VOL. IO6] tion. In Igog a scholarship of the annual value of $50 l$. was founded by Lord and Lady Sheffield; in I9I2 a munificent bequest of $10,000 l$. by Lord Wandsworth was allotted by Sir William Bennett for the institution of a scholarship; and in the same year a sum of $70,000 l$. was collected for general purposes by $\mathrm{Mr}$. Austen Chamberlain as a filial tribute to the memory of the founder.

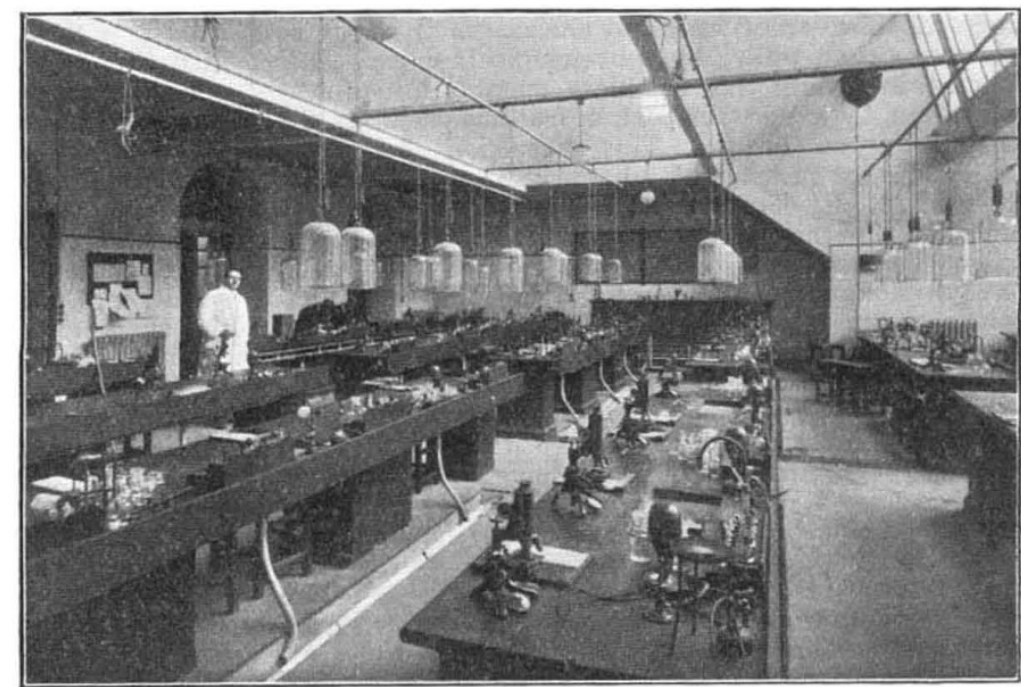

FIG. 2.-A portion of the class laboratory, London School of Tropical Medicine.

The war, which revealed so clearly to this island its dumb dependence on the unconquerable soul of the merchant seaman, brought at its close to the Seamen's Hospital Society a practical expression of gratitude and admiration so full as to reflect some of its splendour on the society's Tropical School. As a tribute to the dauntless spirit maintained during the 
war by the merchant seaman, the British Red Cross Society and the Society of St. John together gave to the Seamen's Hospital Society the sum of $100,000 l$. for the purchase of the large building in Endsleigh Gardens which had been used in war-time as an officers' hospital, and for its endowment as a hospital in the first instance for sailors and soldiers who had contracted tropical diseases on service, and ultimately for the sailors in perpetuity. Room in this new Hospital for Tropical Diseases being available, the society decided that the kindred school should be included in the project. This decision was applauded by the school's sponsors at the Colonial Office, and by the stimulating influence of Lord Milner it attracted the necessary financial cooperation of a liberal and appreciative section of the public. Early in the year 1920, therefore, the school was translated from the remote, uncouth neighbourhood of the docks to an accessible London quarter strong in academic associations.

Re-established under such favourable auspices in a central position, the school now prosecutes its original design in all its fullness with an ampler staff and equipment. The well-avouched scheme of a main laboratory course, supplemented by clinical demonstrations and a system of lectures, is unchanged, as it both meets the wants of the man who already has some knowledge of tropical conditions and inspires the man to whom tropical responsibilities are prospective. The clinical instruction, moreover, which appeals so strongly to the practitioner coming home for a season for professional rejuvenation, is improved by the institution of a special clinical laboratory attached directly to the hospital and administered by its staff.
It is, however, to the advanced student-to the inquirer whose interests are not entirely engrossed in medical practice and who appreciates the unlimited opportunities for research that the tropics affordthat the recent developments of the school are more particularly adapted. The departments of protozoology, medical entomology, and helminthology have been reconstituted as distinct units, leaving the original nucleus of tropical pathology as a fourth independent unit. Each unit has its own director, assistant, and subordinate staff, and is equipped to accommodate the individual student who contemplates pursuing some special line of study abroad, or desires to work out particular material collected abroad, or has some set object of his own outside any participation in the general laboratory course in which all the departments co-operate as before. By this arrangement, which also permits a director or an assistant alternatively to go abroad without disturbance of the home routine, research in tropical medicine is doubly seconded. The advanced or special student will also benefit by the proximity of the Tropical Diseases Bureau, which is now housed with the school, and is about to permit a considerable part of its books and serials to be incorporated, as a permanent loan, in a common library.

The changes thus briefly outlined, however, illustrate that inexorable concatenation of pain with pleasure which supplied one of the texts of Socrates' valedictory discourse; for much as the school has gained by its removal, it has lost--for the present, whatever recompense may lie in the womb of Timethe mess and all the concurrent social amenities which graced its old home in the wilderness.

\section{New Experiments on the Inheritance of Somatogenic Modifications.}

\section{By Prof. Arthur Dendy, F.R.S.}

$\mathrm{I}^{\mathrm{T}}$ has long been suspected that the problem of the transmission from parent to offspring of somatogenic modifications ("acquired characters") might be solved more readily by physiological experiments directly involving the complex metabolism of the body than by crude surgical operations such as the amputation of limbs. This suspicion has been justified in a remarkable manner by the work of Messrs. M. F. Guyer and E. A. Smith, recently published in the Journal of Experimental Zoology under the general title "Studies on Cytolysins." The physiologists, through their brilliant investigations of serum reactions, have placed a whole armoury of new weapons in the hands of the zoologist, and have even furnished him with a chemical means of determining the degree of relationship, and consequently the correct systematic position, of different "species" of animals. We now have to thank them for giving us a new means of approach to what is perhaps the most difficult problem in biological science.

It has been known for some time that the injection of foreign proteids into the blood of a vertebrate animal calls forth a most profound physiological response, and Messrs. Guver and Smith have taken full advantage of this knowledge in devising their experiments. Bordet showed a quarter of a century ago that when the red corpuscles of the rabbit are repeatedly iniected into the blood of the guinea-pig the latter acquires the power of destroying them, and serum prepared from these "sensitised" guinea-pigs

1 "Some Prenatal "ffects of Lens Antibndie:" (Journ. Exp. Zool., vol. xxvi., May, '918): "Trancmission of Induced Eye Defects" (op. cit., vol, xxxi., August, rozo). NO. 2675 , VOL. IO6] will rapidly dissolve the red corpuscles of the rabbit in vitro, while the serum of untreated guinea-pigs has little or no effect. This experiment formed the commencement of our knowledge of a whole class of substances known as "cytolysins,", which appear in the blood as the appropriate "antibodies" in response to the injection of such substances as red corpuscles, leucocytes, nervous tissue, spermatozoa, and crystalline lens, all of which, "when injected into the blood of an unrelated species, will form lytic substances more or less specific for the antigen used in the sensitising process," the antigens being presumably the characteristic proteids of the substances injected.

The "antibody" or "antitoxin" may be produced in large excess of the amount actually required to destroy the injected foreign proteid, and a highly sensitised serum may thus be obtained. It was with such a serum, sensitised to the crystalline lens of the rabbit, that Messrs. Guyer and Smith conducted their experiments. The serum was prepared by grinding up rabbits' lenses with normal salt solution and injecting the fluid into fowls. A "lens-sensitised" serum was thus obtained, i.e. a serum which would dissolve the lens-substance of the rabbit.

When this lens-sensitised serum is injected into the veins of a pregnant rabbit the youns exhibit a tendency to develop defective eyes-especially as regards the lens, which may be more or less opaque or liauefied. The eyes of the parent are not affected, possibly because in the adult eve the blood-supply to the lens is so meagre that the sensitised serum cannot reach it, or the adult lens may be too tough to be affected by minute quantities of the lysin. The lens of the developing embryo, however, is a very 